\title{
Influence of salinity and sediment resuspension on macrophyte germination in coastal lakes
}

\author{
Tim STEINHARDT and Uwe SELIG* \\ University of Rostock, Institute of Bio Science, Albert-Einstein-Str. 3, 18051 Rostock, Germany \\ *e-mail corresponding author: uwe.selig@uni-rostock.de
}

\begin{abstract}
The vegetation as well as diaspore banks were investigated in two coastal lakes on the German Baltic Coast. The distribution of vegetation and diaspores was analysed at two depths $(0.5,1.5 \mathrm{~m})$ on transects. Seedling densities and germination rates of the diaspore banks were determined in a laboratory study that investigated dependencies on salinity and sediment resuspension. The vegetation study yielded five taxa in both lakes: 3 angiosperm taxa and 2 charophytes. In contrast to the poorly developed vegetation, the diaspore bank was represented by 12 taxa(-groups). The germination experiments showed five taxa. Chara contraria A. Br. ex Kütz. was the dominant species. The seedling density of this species was significantly lower at the highest salinity after sediment resuspension in one of the two lakes. The second lake showed a significantly lower seedling density at the highest salinity only for one water depth before sediment resuspension. After sediment resuspension within a salinity level, the seedling density and germination rate were as high as prior to this disturbance. Sediment resuspension can buffer the recolonisation from the sediment diaspore bank of Chara contraria after drawdown.
\end{abstract}

Key words: charophytes, coastal lakes, eutrophication, germination, recolonisation, seed bank

\section{INTRODUCTION}

Coastal lakes are lakes, located in coastal areas, which are isolated from the sea by a barrier but connected to it by an inlet. The water exchanges of these lakes were regulated by inflow of freshwater from the catchment area and outflow in the open Sea. However, they are characterized by fluctuations in salinity, temperature, water level, and dissolved oxygen, which restrict the number of species in these environments. With increasing use of the catchment area for agriculture and in line with the demands of coastal protection, narrow connections to the open Sea have become more regulated by culverts. This has reduced the water exchange with the open Sea. The result is a salinity decrease and a change to limnic conditions in these coastal lakes. This change of salinity has been accompanied by an increased nutrient influx from the catchment area. Higher nutrient influx was due to increased agriculture and the construction of canals. The increase in trophic status in the coastal lakes led to a decrease of submersed vegetation and a dominance of phytoplankton.

With the implementation of the European Water Framework Directive (EU-WFD) a good ecological status must be achieved by 2015 for all lakes $>50$ ha. For the coastal lakes on the Baltic Sea, the recent status was described as poor and bad ecological status (Sagert et al. 2008). As a management strategy to improve ecological status and for the reconstruction of the natural conditions of these lakes, the culvert will be opened. This strategy is designed to improve the light conditions in the lakes and to increase the depth distribution of submersed macrophytes as well as to increase the salinity.

An important indicator reflecting improved ecological status of coastal lakes is the development of charophytes. Blindow (2000) described the increase in light availability and decrease in nutrient and chlorophyll concentrations in connection with the development of dense charophyte vegetation. Accordingly, macrophyte recolonisation is one aim of the implementation of the EU-WFD. Vegetative propagules (bulbils, vegetative fragments) and germination of oospores (diploid zygotes) are the main charophyte colonisation strategies. Oospores are the main component of seed banks in sediments and show a persistence characterised by dormancy and longevity (Casanova \& Brock 1990; de Winton \& Clayton 1996; de Winton et al. 2000; Bonis $\&$ Grillas 2002). Charophyte vegetation has considerable benefits for the management of shallow eutrophic lakes (Clayton \& Tanner 1988; van den Berg et al. 1998). Their dense stocks protect lake sediments against wave disturbance (James et al. 2004). They also have a strong mitigating influence on water turbidity (van den Berg et al. 1998; Casanova et al. 2003). On the other hand, charophytes are vulnerable to decline and subject to replacement by angiosperms (Blindow 1992; Wells et al. 1997). Such competitive angiosperms grow mainly by vegetative means (vegetative fragments, tubers) and seldom by seeds.

The aims of this study were to compare the status of the diaspore banks of two coastal lakes and to investigate their germination potential depending on salinity and sediment resuspension. We assumed that diaspore 
species and their quantities were similar for both lakes. Lab experiments were conducted to examine the recolonisation potential of macrophytes in the coastal lakes as a function of saltwater exchange. We predicted a decrease in the germination rate with increasing salinity and after a sediment resuspension event because the amount of viable oospores decreases after germination.

\section{MATERIAL AND METHODS}

\subsection{Study areas}

The Baltic coast of Germany consists of many coastal lakes with more or less narrow and regulated connections to the open Baltic Sea. The salinity of these lakes ranges from 0.5 (oligohaline) to 11 ( $\alpha$-mesohaline) (Sagert et al. 2008). Two of these coastal lakes were investigated in this study: the Grosser Binnensee (GB) and the Windebyer Noor (WN). They are located at the Hohwachter Bight (GB: $\left.9^{\circ} 48.220^{\prime} \mathrm{E}, 54^{\circ} 28.260^{\prime} \mathrm{N}\right)$ and at the Eckernförder Bight (WN: $10^{\circ} 37.330^{\prime} \mathrm{E}, 54^{\circ} 19.330^{\prime} \mathrm{N}$ ) of the northwest German Baltic coast. Some of the morphometric and hydrographical parameters like lake volume, catchment area, maximum depth and salinity differ much between the two lakes (Tab. 1). According to the Venice system (Caspers 1959) the lakes can be classified as limnic (GB) and oligohaline (WN) by the recent salinity.

Tab. 1. Morphometric and hydrographical parameters of both lakes (data from Seensteckbriefe of the country Schleswig-Holstein: http://www.umweltdaten.landsh.de in Sagert 2008).

\begin{tabular}{lcc}
\hline & $\begin{array}{c}\text { Großer Binnensee } \\
(\mathrm{GB})\end{array}$ & $\begin{array}{c}\text { Windebyer Noor } \\
(\mathrm{WN})\end{array}$ \\
\hline Lake area $\left[\mathrm{km}^{2}\right]$ & 4.8 & 3.9 \\
Lake volume $\left[10^{6} \mathrm{~m}^{3}\right]$ & 9.0 & 25.0 \\
Catchment area $\left[\mathrm{km}^{2}\right]$ & 146 & 16.9 \\
Max. depth [m] & 3 & 14 \\
Salinity [PSU] & 0.4 & 1.4 \\
TP $\left[\mathrm{mg} \mathrm{L}^{-1}\right]$ & 0.14 & 0.14 \\
TN $\left[\mathrm{mg} \mathrm{L}^{-1}\right]$ & 1.825 & 1.2 \\
Chl a $\left[\mu \mathrm{g} \mathrm{L}^{-1}\right]$ & 79 & 73 \\
Secchi depth $[\mathrm{m}]$ & 0.4 & 0.6 \\
\hline
\end{tabular}

The GB is a shallow, unstratified water body with a mean depth of $1.9 \mathrm{~m}$ (maximum $3 \mathrm{~m}$ ), a surface area of $4.8 \mathrm{~km}^{2}$ and a catchment area of $146 \mathrm{~km}^{2}$. The Kossau River is the major inflow. The lake has a closed culvert to the Baltic Sea and there is no salinity gradient within the lake. Larson and Pohl (2006) modelled natural salinity without culvert as ranging from 8 to 10 PSU. The WN is a dimictic stratified lake with a mean depth of $6.4 \mathrm{~m}$ (maximum $14 \mathrm{~m}$ ), a surface area of $3.9 \mathrm{~km}^{2}$ and a catchment area of $16.9 \mathrm{~km}^{2}$. This lake is also closed by culvert to the Baltic Sea and lacks a salinity gradient. The pristine salinity without culvert ranged from 4.5 PSU in the 1920s (Lüders 1972) to 2.5 PSU in 1988 (Kuhnt et al. 1990). Both waters are nutrientenriched and were classified as polytrophic according to the limnic lake classification system (LAWA 1998).
Larson and Pohl (2006) modelled the salinity resulting from a potential opening of the culverts. The two water regulating scenarios yielded salinity values of 4 PSU (scenario 1) and 8 PSU (scenario 2). That study was the basis for the salinity levels in the present germination experiments.

\subsection{Vegetation analysis}

The vegetation was investigated in June and August, 2007. The cover of submersed vegetation was measured as the mean of five $1 \mathrm{~m}^{2}$ quadrat areas at each of five sampling points located at depths of $0.5 \mathrm{~m}$ and $1.5 \mathrm{~m}$ in both lakes. Charophytes were determined to species level following Krause (1997). Angiosperm macrophytes were identified following Rothmaler et al. (1994). The percent cover of each plant species was estimated using a modified and combined Braun-Blanquet abundance dominance scale. Values were converted into mean percent cover values: $0.1 \%=1$ specimen; $0.2 \%$ $=2$ to 5 specimens; $2.5 \%=\sim 5 \%$ cover but $<50$ specimens; $5 \%=\sim 5 \%$ cover but $>50$ specimens; $10 \%=5$ to $15 \%$ cover; $20 \%=>15$ to $25 \%$ cover; $37.5 \%=>25$ to $50 \%$ cover; $62.5 \%=>50$ to $75 \%$ cover; $87.5 \%=>75$ to $100 \%$ cover for the calculations (Ellenberg 1992).

\subsection{Diaspore bank analysis}

Sediment samples were collected with a Plexiglas sediment corer at water depths of $0.5 \mathrm{~m}$ and $1.5 \mathrm{~m}$. Five sampling points were investigated at each depth, resulting in ten samples for each lake. Four cores, each $5 \mathrm{~cm}$ long and with an internal diameter of $6 \mathrm{~cm}$, were complied extracted from each sampling point, yielding a sample volume of $\sim 570 \mathrm{~mL}$. These cores were mixed and washed with a sieving machine and a jet of water through sieves with $1,0.5$ and $0.2 \mathrm{~mm}$ aperture mesh. Residues were dried at $60{ }^{\circ} \mathrm{C}$ for $12 \mathrm{~h}$. These three fractions were inspected under a dissecting microscope. All diaspores in the residue of the $1 \mathrm{~mm}$ fraction were counted. The 0.5 and $0.2 \mathrm{~mm}$ fractions were each homogenised by careful mixing with a spatula to obtain random subsamples. A subsample of $25 \%$ of the $0.5 \mathrm{~mm}$ fraction and a subsample of $10 \%$ of the $0.2 \mathrm{~mm}$ fraction was completely investigated. These subsamples were examined by spreading 2-3 g of the subsample material over a Petri plate. Graph paper was glued to the bottom of the Petri plate to enable the inspection of the part of the subsamples within $1 \mathrm{~cm}$ sectors (Ostendorp 1998). The subsample counts were extrapolated to $100 \%$ and converted to diaspore numbers per $\mathrm{m}^{2}$. Four cores together represented a sediment surface of $1.13 \times 10^{-2} \mathrm{~m}^{2}$, enabling the calculation of diaspore numbers per $1 \mathrm{~m}^{2}$ and comparisons between other coastal waters.

Diaspores were identified to genus or species level using keys by Bertsch (1941) and Beijerinck (1947) for seeds. The literature by Krause (1997), Wood and Imahori (1965), Soulié-Märsche (1989) and a key of Vedder (2004) were used to identify oospores. The latter key 
did not always allow determination to species level. This procedure yielded groups of oospore types to which species could be assigned: The Chara asperal canescens-group contained the species Chara aspera Dethard. ex Willd. and Chara canescens Des. \& Loisl. and the Chara vulgaris/contraria-group the species Chara vulgaris L. and C. contraria. The Chara aspera/vulgaris-group consisted of C. aspera, C. canescens, C. vulgaris and C. contraria. The Chara globularis/delicatula-group contained the species Chara globularis Thuill. and Chara delicatula Agardh. The Chara hispida/baltica-group consisted of Chara hispida L. (Hartm.) and Chara baltica Bruzelius.

\subsection{Germination laboratory experiments}

In addition to the diaspore bank analysis, sediment samples for germination tests were collected with a Plexiglas sediment corer. The samples from GB were kept for 1 week, those from WN for 12 weeks in a cold store at $10{ }^{\circ} \mathrm{C}$ in darkness. Five sampling points were investigated at each water depth $(0.5 \mathrm{~m}$ and $1.5 \mathrm{~m})$, resulting in ten samples for each lake. Four cores, each $5 \mathrm{~cm}$ long and with an internal diameter of $10 \mathrm{~cm}$, were extracted from each sampling point, yielding a sample volume of around $1600 \mathrm{~mL}$. These cores were carefully mixed and each sample was divided into 9 subsamples, yielding 9 beakers with a sediment layer of $5 \mathrm{~cm}$. Every 3 beakers of a sample were filled with $300 \mathrm{~mL}$ natural lake water and water with salinities of 4 and 8 PSU, the levels of the investigated factor salinity. The salinity was measured using Practical Salinity Units (PSU). Natural water of the respective lake and Baltic Sea water (salinity 14 PSU) were filtered through a $0.45 \mu \mathrm{m}$ filter and mixed to yield a salinity of 4 PSU and 8 PSU. The beakers were stored in a water cooled tank at $15^{\circ} \mathrm{C}$. The sample water was oxygenated and the sediment samples exposed to light at $100 \pm 20 \mu \mathrm{mol}$ photons $\mathrm{m}^{-2}$ $\mathrm{s}^{-1}$ over a $12 \mathrm{~h} \mathrm{light}$ and $12 \mathrm{~h}$ darkness period.

After 12 weeks (first phase of experiment) the seedlings with rhizoids, bulbils and oospores were removed from the sediment with a forceps. The seedling density and the germination rate level were measured as response variables for each salinity. To calculate the germination rate the seedlings that germinated from oospores were counted and calculated as the ratio of oospore germinated seedlings to oospores in the diaspore bank analysis of a sampling site. The lengths of the rhizoids between the germinated oospores and the transition of the white rhizoid to the chlorophyll containing (green) part (sediment surface) were measured with a ruler to calculate the depth distribution of the germinated oospores in the upper $5 \mathrm{~cm}$ of the sediment. The seedlings were identified to species level using determination keys by Krause (1997) as well as van de Weyer and Schmidt (2007).

For the investigation of the effects of sediment resuspension on germination (second phase of experi- ment), the sample water was poured off and the sediment carefully mixed with a spoon to simulate a sediment resuspension. Afterwards the sample water was added and the beakers were stored for another 12-week period at the same light and temperature conditions. The analysis of the factor sediment resuspension took place in comparison of the seedling density before (first phase of the experiment) and after sediment resuspension (second phase of experiment). In the interpretation of the factor sediment resuspension, the seedling density and germination rate before and after sediment resuspension were compared.

\subsection{Statistical analysis}

The Mann-Whitney U-test using SPSS was performed between the two lakes on the diaspore numbers counted from sieved sediment samples for each investigated water depth $0.5 \mathrm{~m}$ and $1.5 \mathrm{~m}(\mathrm{n}=10)$ for the Chara aspera/canescens-group, Chara vulgaris/contrariagroup, Chara aspera/vulgaris-group and Tolypella nidifica. The other diaspore taxa and vegetation taxa were not tested because of too many zero values.

Nonparametric ANOVA for dependent variables was performed on the within lake comparison of the germination data of Chara contraria. The Friedmanntest and the Wilcoxon-test were used to show differences between the three salinity levels for the seedling density and the germination rate for each water depth (n $=15$ ); the Wilcoxon-test was also performed on the seedling density and the germination rate to show differences before and after sediment resuspension for each salinity level and each water depth $(\mathrm{n}=10)$.

\section{RESULTS}

\subsection{Recent vegetation and diaspore bank}

The vegetation study yielded only five taxa in 2007 in both lakes: 3 angiosperm taxa and 2 charophytes (Tab. 2). Only Zannichellia palustris and Potamogeton pectinatus were found in both lakes and both water depths. In GB the vegetation cover of Zannichellia palustris was lower at $0.5 \mathrm{~m}$ than in $1.5 \mathrm{~m}$, where the highest vegetation cover for this species was observed in both lakes. In $\mathrm{WN}$ the vegetation cover of Zannichellia palustris was lower at $1.5 \mathrm{~m}$ than at $0.5 \mathrm{~m}$. Potamogeton pectinatus had almost the same cover in both depths in GB and was much higher than in WN. For this species the vegetation cover was higher at $0.5 \mathrm{~m}$ versus $1.5 \mathrm{~m}$ in WN. Potamogeton friesii and Chara contraria were only found at $0.5 \mathrm{~m}$ in $\mathrm{GB}$, whereby the former species was rare in this lake and the latter species had a high coverage in GB. Chara aspera was found only at $0.5 \mathrm{~m}$ depth with moderate cover in WN.

The diaspore bank analysis for GB and WN yielded a total of 12 taxa of submersed types: 3 angiosperm taxa groups and 9 charophyte taxa groups (Tab. 2). Some diaspores were not recorded in WN: the Potamogeton 
Tab. 2. Diaspore densities and vegetation cover (mean (SD), $n=5$ ) and significance level $P$ of U-tests of differences in diaspore

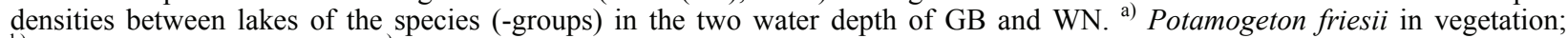

b) Chara aspera in vegetation; ${ }^{\text {c) }}$ Chara contraria in vegetation; n.s.: not significant; -: not tested.

\begin{tabular}{|c|c|c|c|c|c|c|}
\hline \multirow[t]{2}{*}{ Species (groups) } & \multirow{2}{*}{$\begin{array}{c}\text { Differ. in diaspore } \\
\text { densities } \\
\text { P }\end{array}$} & \multirow[b]{2}{*}{$\begin{array}{l}\text { Depth } \\
{[\mathrm{m}]}\end{array}$} & \multicolumn{2}{|c|}{ GB } & \multicolumn{2}{|c|}{ WN } \\
\hline & & & $\begin{array}{c}\text { Diaspore density } \\
{\left[\mathrm{m}^{-2}\right]}\end{array}$ & $\begin{array}{c}\text { Vegetation cover } \\
{[\%]}\end{array}$ & $\begin{array}{c}\text { Diaspore density } \\
{\left[\mathrm{m}^{-2}\right]}\end{array}$ & $\begin{array}{c}\text { Vegetation cover } \\
{[\%]}\end{array}$ \\
\hline Zannichellia palustris & $\begin{array}{l}- \\
-\end{array}$ & $\begin{array}{l}0.5 \\
1.5\end{array}$ & $\begin{array}{l}1675(1339) \\
1050(1662)\end{array}$ & $\begin{array}{c}1(0) \\
15(0)\end{array}$ & $\begin{array}{l}200(381) \\
125(177)\end{array}$ & $\begin{array}{l}7(9) \\
1(0)\end{array}$ \\
\hline Ruppia maritima/cirrhosa-group & $\begin{array}{l}- \\
-\end{array}$ & $\begin{array}{l}0.5 \\
1.5\end{array}$ & $\begin{array}{c}0 \\
1025(2292)\end{array}$ & $\begin{array}{l}0 \\
0\end{array}$ & $\begin{array}{c}100(137) \\
50(112)\end{array}$ & $\begin{array}{l}0 \\
0\end{array}$ \\
\hline Potamogeton pusillus/friesii-group ${ }^{\text {a) }}$ & $\begin{array}{l}- \\
-\end{array}$ & $\begin{array}{l}0.5 \\
1.5\end{array}$ & $\begin{array}{c}875(1754) \\
25(56)\end{array}$ & $\begin{array}{c}2(2) \\
0\end{array}$ & $\begin{array}{l}0 \\
0\end{array}$ & $\begin{array}{l}0 \\
0\end{array}$ \\
\hline Potamogeton pectinatus & $\begin{array}{l}- \\
-\end{array}$ & $\begin{array}{l}0.5 \\
1.5\end{array}$ & $\begin{array}{l}0 \\
0\end{array}$ & $\begin{array}{l}36(33) \\
32(18)\end{array}$ & $\begin{array}{l}0 \\
0\end{array}$ & $\begin{array}{c}12(16) \\
3(2)\end{array}$ \\
\hline Chara aspera (freshwater) & - & $\begin{array}{l}0.5 \\
1.5\end{array}$ & $\begin{array}{l}4075(5904) \\
1500(1369)\end{array}$ & $\begin{array}{l}0 \\
0\end{array}$ & $\begin{array}{c}750(1118) \\
0\end{array}$ & $\begin{array}{l}0 \\
0\end{array}$ \\
\hline Chara aspera/canescens-group ${ }^{\text {b) }}$ & $\begin{array}{l}\text { n.s. } \\
\text { n.s. }\end{array}$ & $\begin{array}{l}0.5 \\
1.5\end{array}$ & $\begin{array}{c}14100(18141) \\
9350(8150)\end{array}$ & $\begin{array}{l}0 \\
0\end{array}$ & $\begin{array}{c}22625(25644) \\
4625(7642)\end{array}$ & $\begin{array}{c}9(20) \\
0\end{array}$ \\
\hline (hara vulgaris/contraria-group ${ }^{c)}$ & $\begin{array}{c}\text { n.s. } \\
0.047\end{array}$ & $\begin{array}{l}0.5 \\
1.5\end{array}$ & $\begin{array}{c}21500(17619) \\
1475(1567)\end{array}$ & $\begin{array}{c}31(37) \\
0\end{array}$ & $\begin{array}{l}38700(26342) \\
35600(46933)\end{array}$ & $\begin{array}{l}0 \\
0\end{array}$ \\
\hline Chara aspera/vulgaris-group & $\begin{array}{l}\text { n.s. } \\
\text { n.s. }\end{array}$ & $\begin{array}{l}0.5 \\
1.5\end{array}$ & $\begin{array}{c}57525(42582) \\
12350(6109)\end{array}$ & $\begin{array}{l}0 \\
0\end{array}$ & $\begin{array}{c}24000(16288) \\
5675(6706)\end{array}$ & $\begin{array}{l}0 \\
0\end{array}$ \\
\hline Chara globularis/delicatula-group & $\begin{array}{l}- \\
-\end{array}$ & $\begin{array}{l}0.5 \\
1.5\end{array}$ & $\begin{array}{c}2425(5422) \\
0\end{array}$ & $\begin{array}{l}0 \\
0\end{array}$ & $\begin{array}{l}0 \\
0\end{array}$ & $\begin{array}{l}0 \\
0\end{array}$ \\
\hline Chara hispida & $\begin{array}{l}- \\
-\end{array}$ & $\begin{array}{l}0.5 \\
1.5\end{array}$ & $\begin{array}{l}5200(9205) \\
800(1010)\end{array}$ & $\begin{array}{l}0 \\
0\end{array}$ & $\begin{array}{c}0 \\
100(224)\end{array}$ & $\begin{array}{l}0 \\
0\end{array}$ \\
\hline Chara baltica & - & $\begin{array}{l}0.5 \\
1.5\end{array}$ & $\begin{array}{c}0 \\
100(224)\end{array}$ & $\begin{array}{l}0 \\
0\end{array}$ & $\begin{array}{l}0 \\
0\end{array}$ & $\begin{array}{l}0 \\
0\end{array}$ \\
\hline Chara hispida/baltica-group & $\begin{array}{l}- \\
-\end{array}$ & $\begin{array}{l}0.5 \\
1.5\end{array}$ & $\begin{array}{l}125(217) \\
25(56)\end{array}$ & $\begin{array}{l}0 \\
0\end{array}$ & $\begin{array}{l}0 \\
0\end{array}$ & $\begin{array}{l}0 \\
0\end{array}$ \\
\hline Tolypella nidifica & $\begin{array}{l}\text { n.s. } \\
\text { n.s. }\end{array}$ & $\begin{array}{l}0.5 \\
1.5\end{array}$ & $\begin{array}{l}37100(37889) \\
28925(50034)\end{array}$ & $\begin{array}{l}0 \\
0\end{array}$ & $\begin{array}{c}15325(15777) \\
5750(6065)\end{array}$ & $\begin{array}{l}0 \\
0\end{array}$ \\
\hline
\end{tabular}

pusillus/friesii-group, the Chara globularis/delicatulagroup and Chara baltica. High oospore densities were recorded for the Chara aspera/vulgaris-group at $0.5 \mathrm{~m}$ (GB), and the Chara vulgaris/contraria-group had similar densities as the latter group in both depths in WN. Low oospore densities were recorded for the Potamogeton pusillus/friesii-group at $1.5 \mathrm{~m}$ depth and for Chara baltica and the Chara hispida/baltica-group in the investigated water depth of GB as well as for Zannichellia palustris and the Ruppia maritima/cirrhosa-group at both depths and for Chara hispida at the $1.5 \mathrm{~m}$ depth in WN. The diaspore densities showed mostly no significant differences between the lakes. Only the Chara vulgaris/contraria-group showed a significant difference at $1.5 \mathrm{~m}$ depth (Tab. 2).

\subsection{Germination experiments}

The germination experiments yielded a total of five taxa: one angiosperm and four charophyte species. Chara contraria was the dominant species in both coastal lakes with seedling densities between 345 and $3705 \mathrm{~m}^{-2}$ (Fig. 1). Seedlings of four other species were found with densities lower then $270 \mathrm{~m}^{-2}$ (Tab. 3). Chara canescens and Tolypella nidifica were also found in both lakes, but Chara vulgaris was found only in GB. Potamogeton pectinatus germinated from tubers and shoots and not from seeds in all salinities.

The analysis of the sediment depth of germinated oospores of Chara contraria showed a depth distribution from 0 to $40 \mathrm{~mm}$ (Fig. 2). In GB, most seedlings germinated from oospores in the upper $25 \mathrm{~mm}$ of the sediment. In $\mathrm{WN}$, the corresponding value was the upper $30 \mathrm{~mm}$. Below these sediment depths, germination frequency decreased drastically. These two depths are similar in the two lakes. In GB the highest germination frequency was between 5 and $10 \mathrm{~mm}$, in WN between 0 and $5 \mathrm{~mm}$. Accordingly, the highest germination frequency was in the upper $10 \mathrm{~mm}$ of the sediment in both lakes.

In the germination experiment before sediment resuspension, there was no difference in the seedling densities between salinity levels in both depths in GB (Fig. 1; Tab. 4). Seedling densities did differ between salinities of 2 and $8 \mathrm{PSU}$, but only at $1.5 \mathrm{~m}$ in WN before sediment resuspension.

In the first phase of the germination experiment, the germination rates showed no difference between salinity levels at both depths in both lakes (Fig. 3; Tab. 5). 
Influence of salinity on macrophyte germination in coastal lakes
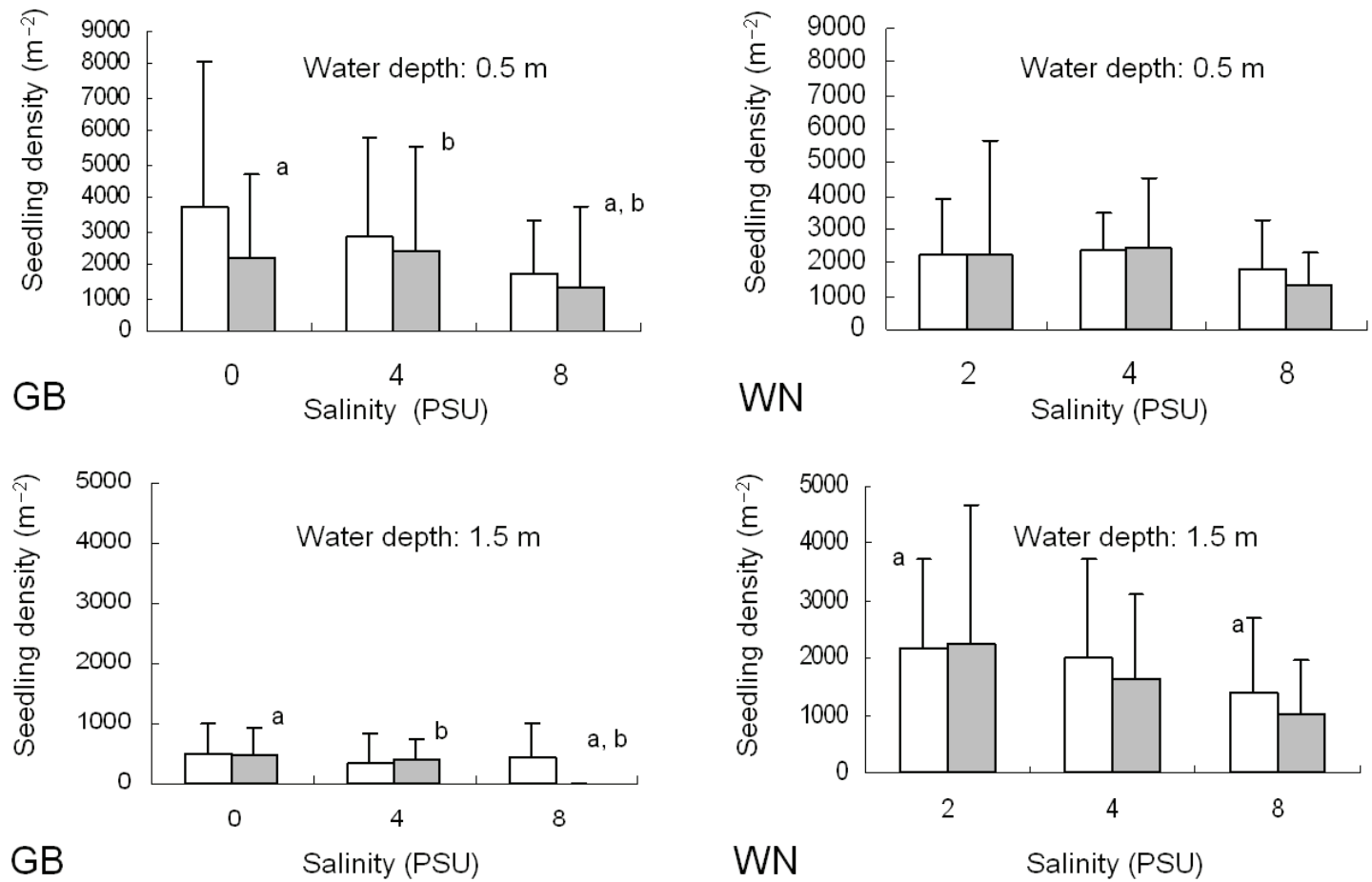

Fig. 1. Seedling densities (mean +1 SD) of Chara contraria for the three investigated salinity levels as well as before (white bar) and after (grey bar) sediment resuspension in the two investigated water depth of the lakes GB and WN (letters a and $\mathbf{b}$ indicate the significant different salinity levels).

Tab. 3. Seedling density $\left[\mathrm{m}^{-2}\right]($ mean $(\mathrm{SD}), \mathrm{n}=5)$ of the species except Chara contraria in the recent salinity state as well as in the investigated salinities and before and after sediment resuspension in GB and WN.

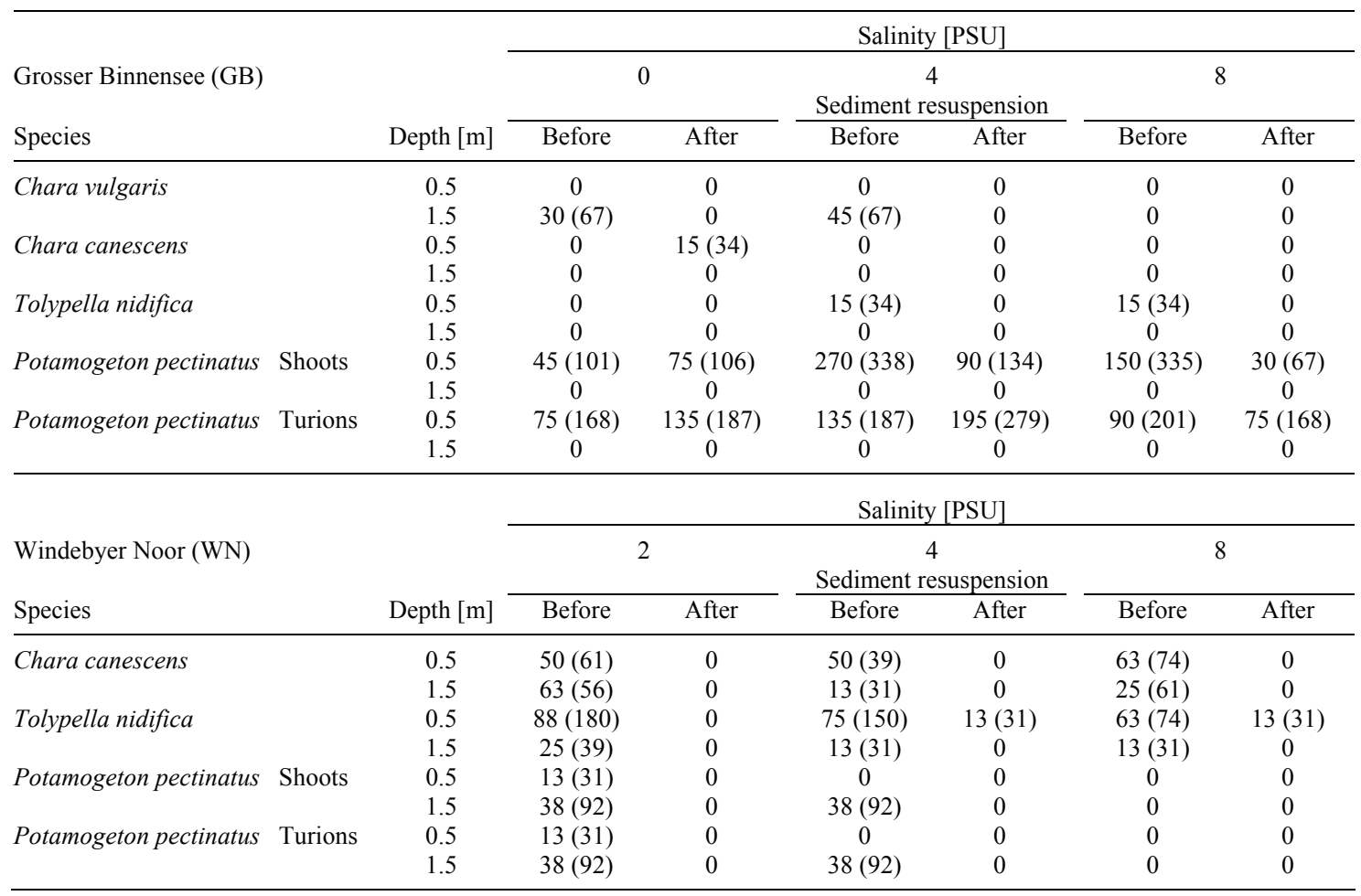



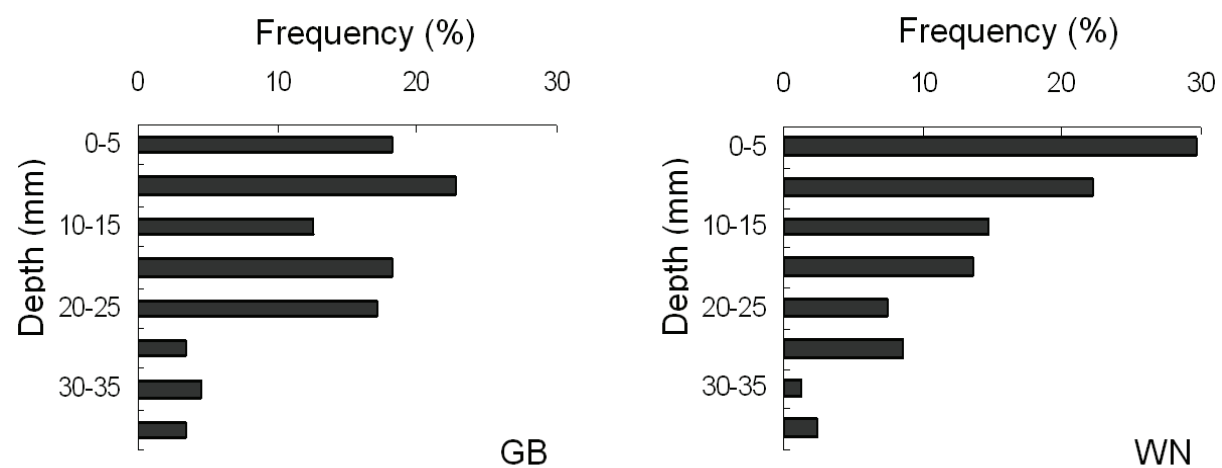

Fig. 2. Frequency of the Chara contraria seedlings germinated from oospores of the depth distribution in sediment in GB and WN.

Tab. 4. Results of Friedman- and Wilcoxon-tests on seedling density between salinity levels and before and after sediment resuspension for Chara contraria in GB and WN.

\begin{tabular}{|c|c|c|c|c|c|c|c|c|c|c|c|}
\hline \multicolumn{4}{|c|}{ Grosser Binnensee (GB) } & \multicolumn{6}{|c|}{ Salinity [PSU] } & \multirow[b]{3}{*}{$\begin{array}{c}\text { Friedman } \\
\text { before }\end{array}$} & \multirow[b]{3}{*}{$\begin{array}{l}\text { Friedman } \\
\text { after }\end{array}$} \\
\hline & \multicolumn{3}{|c|}{0} & \multicolumn{3}{|c|}{4} & \multicolumn{3}{|c|}{8} & & \\
\hline Depth [m] & Before & After & $\begin{array}{l}\text { Wilcoxon } \\
\text { before/after }\end{array}$ & Before & $\begin{array}{l}\text { Sediment } 1 \\
\text { After }\end{array}$ & $\begin{array}{l}\text { resuspension } \\
\text { Wilcoxon } \\
\text { before/after }\end{array}$ & Before & After & $\begin{array}{l}\text { Wilcoxon } \\
\text { before/after }\end{array}$ & & \\
\hline 0.5 & \multicolumn{2}{|c|}{$0 v s 4$ PSU } & & \multicolumn{2}{|c|}{$4 v s 8$ PSU } & & \multicolumn{2}{|c|}{$8 v s 0$ PSU } & & & \\
\hline $\begin{array}{l}\text { Wilcoxon } \\
\text { pairwise }\end{array}$ & $\begin{array}{l}- \\
-\end{array}$ & $\begin{array}{l}\text { P: } 0.345 \\
\text { Z: }-0.944\end{array}$ & $\begin{array}{l}\text { P: } 0.138 \\
Z:-1.483\end{array}$ & - & $\begin{array}{l}\text { P: } 0.043 \\
\text { Z: }-2.023\end{array}$ & $\begin{array}{l}\text { P: } 0.104 \\
\text { Z: }-1.625\end{array}$ & $\begin{array}{l}- \\
-\end{array}$ & $\begin{array}{l}\text { P: } 0.043 \\
\text { Z: }-2.023\end{array}$ & $\begin{array}{l}\text { P: } 0.345 \\
\text { Z: }-0.944\end{array}$ & $\begin{array}{l}P: 0.104 \\
\chi^{2}: 4.526\end{array}$ & $\begin{array}{l}\text { P: } 0.015 \\
\chi^{2}: 8.400\end{array}$ \\
\hline $\begin{array}{c}1.5 \\
\text { Wilcoxon } \\
\text { pairwise }\end{array}$ & $\begin{array}{l}0 v s 4 \\
- \\
-\end{array}$ & $\begin{array}{l}\text { PSU } \\
\text { P: } 0.357 \\
Z:-0.921\end{array}$ & $\begin{array}{l}\text { P: } 0.854 \\
Z:-0.184\end{array}$ & $\begin{array}{l}4 \text { vs } 8 \\
- \\
-\end{array}$ & $\begin{array}{l}\text { PSU } \\
\text { P: } 0.042 \\
\text { Z: }-2.032\end{array}$ & $\begin{array}{l}\text { P: } 0.715 \\
\text { Z: }-0.365\end{array}$ & $\begin{array}{l}8 v s 0 \\
- \\
-\end{array}$ & $\begin{array}{l}\text { PSU } \\
\text { P: } 0.042 \\
Z:-2.032\end{array}$ & $\begin{array}{l}\text { P: } 0.109 \\
\text { Z: }-1.604\end{array}$ & $\begin{array}{l}\text { P: } 0.678 \\
\chi^{2}: 0.778\end{array}$ & $\begin{array}{l}\text { P: } 0.016 \\
\chi^{2}: 8.316\end{array}$ \\
\hline \multicolumn{4}{|c|}{ Windebyer Noor (WN) } & \multicolumn{3}{|c|}{ Salinity [PSU] } & & & & & \\
\hline & \multicolumn{3}{|c|}{2} & \multicolumn{3}{|c|}{4} & \multicolumn{3}{|c|}{8} & & \\
\hline Depth [m] & Before & After & $\begin{array}{l}\text { Wilcoxon } \\
\text { before/after }\end{array}$ & Before & $\begin{array}{l}\text { Sediment } \mathrm{r} \\
\text { After }\end{array}$ & $\begin{array}{l}\text { resuspension } \\
\text { Wilcoxon } \\
\text { before/after }\end{array}$ & Before & After & $\begin{array}{l}\text { Wilcoxon } \\
\text { before/after }\end{array}$ & $\begin{array}{l}\text { Friedman } \\
\text { before }\end{array}$ & $\begin{array}{l}\text { Friedman } \\
\text { after }\end{array}$ \\
\hline 0.5 & \multicolumn{2}{|c|}{$2 v s 4$ PSU } & & \multicolumn{2}{|c|}{4 vs 8 PSU } & & \multicolumn{2}{|c|}{$8 v s 2$ PSU } & & & \\
\hline $\begin{array}{l}\text { Wilcoxon } \\
\text { pairwise }\end{array}$ & $\begin{array}{l}- \\
-\end{array}$ & - & $\begin{array}{l}\text { P: } 0.686 \\
Z:-0.405\end{array}$ & - & - & $\begin{array}{l}\text { P: } 0.500 \\
Z:-0.674\end{array}$ & $\begin{array}{l}- \\
-\end{array}$ & $\begin{array}{l}- \\
-\end{array}$ & $\begin{array}{l}\text { P: } 0.500 \\
Z:-0.674\end{array}$ & $\begin{array}{l}\text { P: } 0.692 \\
\chi^{2}: 0.737\end{array}$ & $\begin{array}{l}\text { P: } 0.607 \\
\chi^{2}: 1.000\end{array}$ \\
\hline $\begin{array}{c}1.5 \\
\text { Wilcoxon } \\
\text { pairwise }\end{array}$ & $\begin{array}{r}2 v s 4 \\
\text { P: } 0.893 \\
\text { Z: }-0.135\end{array}$ & $\begin{array}{r}\text { PSU } \\
- \\
-\end{array}$ & $\begin{array}{l}\text { P: } 0.500 \\
\text { Z: }-0.674\end{array}$ & $\begin{aligned} & 4 v s 8 \\
\text { P: } 0.068 & \\
\text { Z: } & -1.826\end{aligned}$ & $\begin{array}{r}\text { PSU } \\
- \\
-\end{array}$ & $\begin{array}{c}\text { P: } 0.588 \\
Z:-0.542\end{array}$ & $\begin{array}{r}8 v s 2 \\
\text { P: } 0.043 \\
\text { Z: }-2.023\end{array}$ & $\begin{array}{r}\text { PSU } \\
- \\
-\end{array}$ & $\begin{array}{l}\text { P: } 0.465 \\
Z:-0.730\end{array}$ & $\begin{array}{l}\text { P: } 0.040 \\
\chi^{2}: 6.421\end{array}$ & $\begin{array}{l}\text { P: } 0.143 \\
\chi^{2}: 3.895\end{array}$ \\
\hline
\end{tabular}

In GB, Chara vulgaris germinated in salinities of 0 and 4 PSU, Chara canescens did not germinate and Tolypella nidifica germinated in salinities of 4 and 8 PSU before sediment resuspension (Tab. 3). In WN, Chara canescens germinated as expected in all salinity levels, but Tolypella nidifica germinated even in the natural state salinity of 2 PSU.

After sediment resuspension, the seedling densities of Chara contraria differed between salinities of 0 and 8 PSU as well as 4 and 8 PSU at both depths in GB (Fig. 1). The values were significantly lower in a salinity of 8 PSU at the $0.5 \mathrm{~m}$ depth, and there were no seedlings at $1.5 \mathrm{~m}$ in this lake (Fig. 1; Tab. 4). In WN there were no significant seedling density differences between salinity levels after sediment resuspension at either depth. The germination rate was only significantly lower in the salinity of 8 PSU compared to 0 PSU and 4 PSU in $0.5 \mathrm{~m}$ depth in GB after sediment resuspension (Fig. 3; Tab. 5).

In GB, Chara vulgaris and Tolypella nidifica did not germinate after sediment resuspension, but Chara canescens germinated in the salinity of 0 PSU after sediment resuspension. In $\mathrm{WN}$, Chara canescens did not germinate after sediment resuspension, but Tolypella nidifica germinated in the higher salinity levels of 4 PSU and 8 PSU after sediment resuspension. There were no significant differences before and after sediment resuspension within the different salinity levels. This applies for the germination densities and germination rates at both depths and in both lakes (Figs 1 and 3; Tabs 4 and 5). 
Influence of salinity on macrophyte germination in coastal lakes
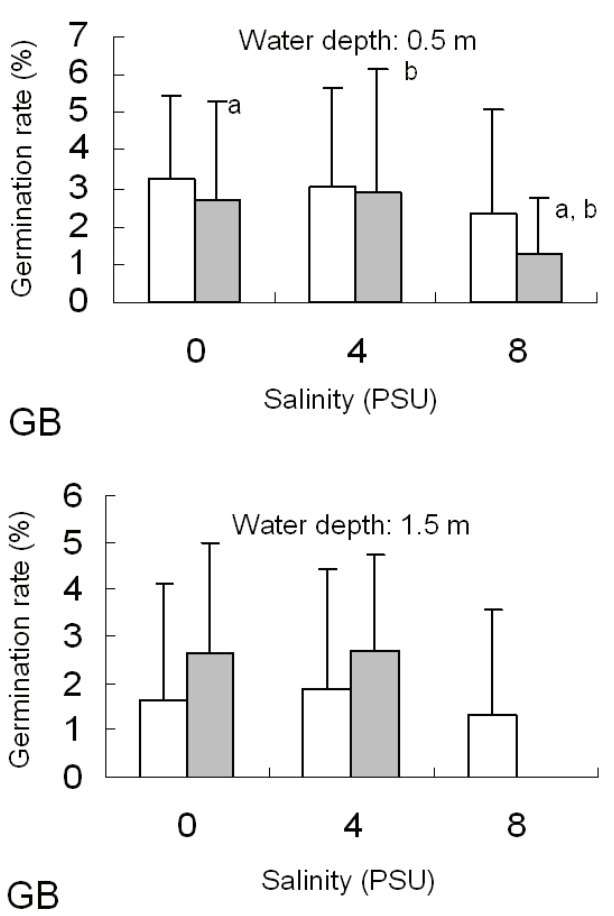
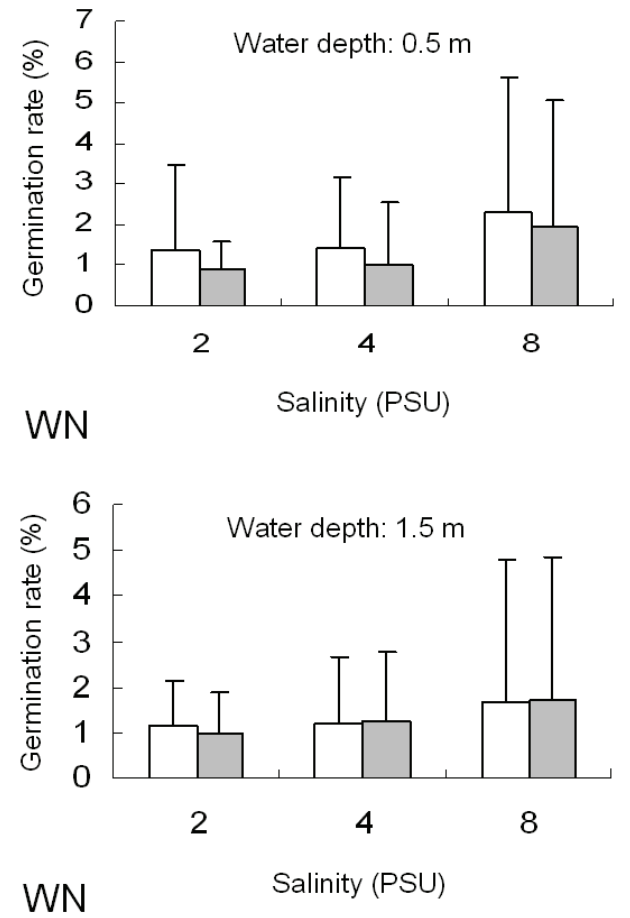

Fig. 3. Germination rates (mean $+1 \mathrm{SD}$ ) of Chara contraria for the three investigated salinity levels as well as before (white bar) and after (grey bar) sediment resuspension in the two investigated water depth of the lakes GB and WN (letters a and $\mathbf{b}$ indicate the significant different salinity levels).

Tab. 5. Results of Friedman- and Wilcoxon-tests on germination rates between salinity levels and before and after sediment resuspension for Chara contraria in GB and WN.

\begin{tabular}{|c|c|c|c|c|c|c|c|c|c|c|c|}
\hline \multicolumn{4}{|c|}{ Grosser Binnensee (GB) } & \multicolumn{6}{|c|}{ Salinity [PSU] } & \multirow[b]{3}{*}{$\begin{array}{c}\text { Friedman } \\
\text { before }\end{array}$} & \multirow[b]{3}{*}{$\begin{array}{l}\text { Friedman } \\
\text { after }\end{array}$} \\
\hline & \multicolumn{3}{|c|}{0} & \multicolumn{3}{|c|}{4} & \multicolumn{3}{|c|}{8} & & \\
\hline Depth [m] & Before & After & $\begin{array}{l}\text { Wilcoxon } \\
\text { before/after }\end{array}$ & Before & $\begin{array}{l}\text { Sediment } \\
\text { After }\end{array}$ & $\begin{array}{l}\text { tresuspension } \\
\text { Wilcoxon } \\
\text { before/after }\end{array}$ & Before & After & $\begin{array}{l}\text { Wilcoxon } \\
\text { before/after }\end{array}$ & & \\
\hline 0.5 & \multicolumn{2}{|c|}{$0 v s 4 \mathrm{PSU}$} & & \multicolumn{2}{|c|}{4 vs 8 PSU } & & \multicolumn{2}{|c|}{$8 v s 0$ PSU } & & & \\
\hline $\begin{array}{l}\text { Wilcoxon } \\
\text { pairwise }\end{array}$ & $\begin{array}{l}- \\
-\end{array}$ & $\begin{array}{l}\text { P: } 0.713 \\
\text { Z: }-0.368\end{array}$ & $\begin{array}{l}\text { P: } 0.273 \\
Z:-1.095\end{array}$ & - & $\begin{array}{l}\text { P: } 0.043 \\
\text { Z: }-2.023\end{array}$ & $\begin{array}{ll}3 & \text { P: } 0.588 \\
3 & \text { Z: }-0.542\end{array}$ & $\begin{array}{l}- \\
-\end{array}$ & $\begin{array}{l}\text { P: } 0.043 \\
\text { Z: }-2.023\end{array}$ & $\begin{array}{l}\text { P: } 0.225 \\
Z:-1.214\end{array}$ & $\begin{array}{l}\text { P: } 0.115 \\
\chi^{2}: 4.333\end{array}$ & $\begin{array}{l}\text { P: } 0.016 \\
\chi^{2}: 8.316\end{array}$ \\
\hline $\begin{array}{c}1.5 \\
\text { Wilcoxon } \\
\text { pairwise }\end{array}$ & $\begin{array}{l}0 \text { vs } 4 \\
- \\
-\end{array}$ & $\begin{array}{r}\text { PSU } \\
- \\
-\end{array}$ & $\begin{array}{l}\text { P: } 0.180 \\
Z:-0.342\end{array}$ & $\begin{array}{l}4 v s 8 \\
- \\
-\end{array}$ & $\begin{array}{r}\text { PSU } \\
- \\
-\end{array}$ & $\begin{array}{l}\text { P: } 0.593 \\
Z:-0.535\end{array}$ & $\begin{array}{l}8 v s \\
- \\
-\end{array}$ & $\begin{array}{r}\text { PSU } \\
- \\
-\end{array}$ & $\begin{array}{l}\text { P: } 0.317 \\
Z:-1.000\end{array}$ & $\begin{array}{l}\text { P: } 0.273 \\
\chi^{2}: 2.600\end{array}$ & $\begin{array}{l}\text { P: } 0.086 \\
\chi^{2}: 4.909\end{array}$ \\
\hline \multicolumn{4}{|c|}{ Windebyer Noor (WN) } & \multicolumn{3}{|c|}{ Salinity [PSU] } & & & & & \\
\hline & \multicolumn{3}{|c|}{2} & \multicolumn{3}{|c|}{4} & \multicolumn{3}{|c|}{8} & & \\
\hline Depth $[\mathrm{m}]$ & Before & After & $\begin{array}{l}\text { Wilcoxon } \\
\text { before/after }\end{array}$ & Before & $\begin{array}{l}\text { Sediment } \\
\text { After }\end{array}$ & $\begin{array}{l}\text { tresuspension } \\
\text { Wilcoxon } \\
\text { before/after }\end{array}$ & Before & After & $\begin{array}{l}\text { Wilcoxon } \\
\text { before/after }\end{array}$ & $\begin{array}{l}\text { Friedman } \\
\text { before }\end{array}$ & $\begin{array}{l}\text { Friedman } \\
\text { after }\end{array}$ \\
\hline 0.5 & \multicolumn{2}{|c|}{$2 v s 4$ PSU } & & \multicolumn{2}{|c|}{4 vs 8 PSU } & & \multicolumn{2}{|c|}{$8 v s 2$ PSU } & & & \\
\hline $\begin{array}{l}\text { Wilcoxon } \\
\text { pairwise }\end{array}$ & - & - & $\begin{array}{l}\text { P: } 0.786 \\
\text { Z: }-0.271\end{array}$ & - & $\begin{array}{l}- \\
-\end{array}$ & $\begin{array}{l}\text { P: } 0.461 \\
\text { Z: }-0.736\end{array}$ & $\begin{array}{l}- \\
-\end{array}$ & - & $\begin{array}{l}\text { P: } 0.480 \\
\text { Z: }-0.707\end{array}$ & $\begin{array}{l}\text { P: } 0.646 \\
\chi^{2}: 0.875\end{array}$ & $\begin{array}{l}\text { P: } 0.735 \\
\chi^{2}: 0.615\end{array}$ \\
\hline 1.5 & \multicolumn{2}{|c|}{$2 v s 4 \mathrm{PSU}$} & & \multicolumn{2}{|c|}{4 vs 8 PSU } & & \multicolumn{2}{|c|}{$8 v s 2$ PSU } & & & \\
\hline $\begin{array}{l}\text { Wilcoxon } \\
\text { pairwise }\end{array}$ & - & $\begin{array}{l}- \\
-\end{array}$ & $\begin{array}{l}\text { P: } 0.102 \\
\text { Z: }-1.633\end{array}$ & - & - & $\begin{array}{c}P: 1.000 \\
\text { Z: } 0\end{array}$ & - & $\begin{array}{l}- \\
-\end{array}$ & $\begin{array}{l}\text { P: } 0.593 \\
\text { Z: }-0.535\end{array}$ & $\begin{array}{l}\text { P: } 0.066 \\
\chi^{2}: 5.444\end{array}$ & $\begin{array}{l}\text { P: } 0.115 \\
\chi^{2}: 4.333\end{array}$ \\
\hline
\end{tabular}




\section{DISCUSSION}

\subsection{Diaspore bank-germination relationship}

Based on studies in the coastal waters along the German Baltic Sea (Steinhardt \& Selig 2007, 2009), oospores dominated the diaspore bank in the two coastal lakes investigated here. Diaspore banks are known to have many more taxa than viable diaspore banks (Bonis \& Grillas 2002). In the Grosser Binnensee (GB), five species of the 12 taxa(-groups) found in the sediment germinated; in the Windebyer Noor (WN), four species of the 8 taxa(-groups) germinated. The highest germination densities occurred in taxa(-groups) with the highest diaspore densities in the diaspore bank.

The limited germination rates of Chara contraria oospores from the seedbank (1.3-3.2\% in GB and 0.9$2.3 \%$ in $\mathrm{WN}$ ) could be related to a perennial strategy (Bonis \& Grillas 2002). Low estimated rates may have also been an artefact of the calculation modus used for estimating germination rates because only oospore germinated seedlings were compared with counted oospore numbers from the sediment. Seedlings germinated by bulbils were not considered in the germination rates. Oospores of Chara contraria collected from plants showed a germination rate of $44-85 \%$ while those collected from sediment exhibited a lower germination rate of $30-50 \%$ both germinated at $21{ }^{\circ} \mathrm{C}$ (Sabbatini 1987). Acosta et al. (1999) found similar high germination rates of $24 \%$ for sedimentary oospores of Chara contraria at an unknown temperature. A maximum germination rate for Chara contraria of $36.6 \%$ was found by Acosta et al. (1998) in the optimum range of $24-27^{\circ} \mathrm{C}$, indicating that this species require higher then the mean spring temperature of $15{ }^{\circ} \mathrm{C}$ simulated in our experiments for optimal recolonisation.

Burial to a depth of $5 \mathrm{~mm}$ can improve oospore germination capacity because of the decreasing redox values in the upper few millimeters of the sediment surface. Burial below $20 \mathrm{~mm}$ limits germination because of the decreasing light availability (Bonis \& Grillas 2002). The highest oospore germination frequency in GB was in the upper 5-10 $\mathrm{mm}$, whereas in WN the highest oospore germination took place in the $0-5 \mathrm{~mm}$ range. The lowest burial depth for oospores was at a somewhat higher depth in both lakes (about $25 \mathrm{~mm}$ in GB, $30 \mathrm{~mm}$ in $\mathrm{WN}$ ).

Except for Potamogeton pectinatus, all species found in the vegetation in 2007 could also be detected in the generative diaspore bank in 2008. Also, all the plants studied in the laboratory, except Potamogeton pectinatus, were detected in the generative diaspore bank. In contrast to the charophytes, angiosperms have a high vegetative reproduction potential. Potamogeton pectinatus produces tubers and mainly develops plants from these tubers (van Wijk 1989). In our investigation, the most shoots arose from tubers. Tubers produced by Potamogeton crispus were observed from late May to late October when water temperature was higher than 20
${ }^{\circ} \mathrm{C}$ (Wu et al. 2009) and the photoperiod exceeded $12 \mathrm{~h}$ (Sastroutomo 1981; Kunii 1989). The tubers begin to germinate in autumn and live through the winter.

\subsection{Effects of salinity}

Submersed angiosperms and charophytes show a typical dependency on salinity in inner coastal waters along the Baltic Sea. Salinity is the major factor in the distribution of charophytes and angiosperms here (Selig et al. 2007). In the laboratory experiments, Chara contraria and Chara vulgaris preferred the same salinity range (0-8 PSU and 0-4 PSU, respectively) as given in the literature for the Baltic Sea (Schubert \& Blindow 2003). These two species are typical freshwater species that are usually distributed in a salinity of about 0 PSU. The extension of the upper border of the salinity range was only investigated for $C$. vulgaris.

Chara canescens and Tolypella nidifica are typical brackish water species with a salinity optimum above 0 PSU. They germinated in lower salinities (0 and 2 PSU, respectively, Tab. 3), but also in higher values tested by Schubert and Blindow (2003) (2.3-19.9 and 3-30 PSU, respectively). The formation of mature oospores of Tolypella nidifica is known to occur between 0 and 12 PSU (Winter et al. 1996). The germination in T. nidifica is remarkable because no data are available on germination of this species from natural sediments in the literature. For these two species, the fieldwork shows germination at salinity ranges lower than those the species show under laboratory conditions. The biotic competition apparently reduces the salinity range the species tolerate in the laboratory investigations.

The seedling densities of the limnic Chara contraria tend to be lower in both lakes at a salinity of 8 PSU, or the species was even absent. This effect was stronger in GB. In WN the effects are weaker because of the higher initial experimental salinity of this lake. An increase in salinity resulted in a weaker colonisation by Chara contraria.

Similar effects were evident for the germination rates in GB. Higher salinity can lower the germination rates, especially in shallow water $(0.5 \mathrm{~m})$ in GB. In WN, salinity did not affect the germination rates.

\subsection{Effects of sediment resuspension}

Sediment resuspension events caused by wind or biota mixed the upper sediment layer in shallow lakes. The decrease of seedling densities with increasing salinity in the lakes is better expressed after sediment resuspension. In the second phase the longer influence of salinity decrease the germination rate. A salinity increase alone yielded lower seedling densities in WN at one water depth $(1.5 \mathrm{~m})$, but only between the low and the high salinity. The additional effect of sediment resuspension significantly reduced the seedling densities in GB at both depths at higher salinities of 8 PSU compared to the other both salinities. For the germination 
rates, the additional effect of sediment resuspension was lower and only significant in GB in one water depth. Higher salinity combined with sediment resuspension events caused by wave action, water birds or fishes can result in a lower recolonisation potential of the sediments in GB. In WN, sediment resuspension had no significant effect on seedling densities or germination rates.

Nevertheless, sediment resuspension alone did not result in different seedling densities at all investigated salinities in either lake. Accordingly, sediment resuspension events in the current state of the lakes (after the historical change of the salinity) do not disturb the recolonisation potential of the sediments. In contrast, they can keep it constant after a decay of the vegetation. Otherwise, if dense Chara beds are established, they will restrict sediment resuspension (Kufel \& Kufel 2002) and reduce the colonisation by the sediment diaspore bank.

Light is necessary for charophyte germination and it attenuates rapidly in the upper sediment layer (de Winton et al. 2000). Frankland et al. (1987) found that a soil depth of $5 \mathrm{~mm}$ reduces ambient light to $0.0001 \%$. The germination frequency of oospores decreased with depth in the sediment, and the most likely cue for this germination response was a light gradient through the sediment strata (Dugdale et al. 2001). The oxygen penetration and redox potential decrease with increasing sediment depth. But these changes usually occur rapidly in the upper few millimetres of the sediment layer and thus do not coincide with the decrease of the germination frequency of Chara contraria. In the first phase of our laboratory experiment the seedling densities were determined at a stable sediment-water interface. In shallow lakes or the littoral zone of the lakes, the upper sediment layer is frequently mixed. Under such conditions the oospores from the deeper sediment layers can be transported into the upper sediment horizons. Therefore, in wind-mixed shallow lakes, sediment resuspension and redeposition should increase the seedling densities. This aspect is very important for macrophyte recolonisation after lengthy periods of disappearance. Surviving oospores can be transported into the upper sediment layer during resuspension events and germinate, depending on salinity and light conditions. The large number of viable seeds conserved in deeper layers suggests that the most valuable macrophyte pools are conserved at depth (En-Hua et al. 2008).

This effect was evident in GB for Chara canescens, which germinated after sediment resuspension under the initial salinity conditions. In WN, Tolypella nidifica germinated after sediment resuspension at higher salinities than the initial experimental values.

\section{CONCLUSIONS}

The diaspore bank of both coastal lakes was dominated by oospores. The oospore germination dominated in the germination experiments. The effect of salinity on the germination rate alone was low. Only in one lake and at one water depth was the germination rate of Chara contraria significantly lower at the highest salinity compared to the lowest salinity. Sediment resuspension during the change of the salinity for restoration purposes in the lakes will negatively affect the recolonisation potential of Chara contraria. The seedling densities and germination rates of Chara contraria were before sediment resuspension as high as after sediment resuspension and redeposition. This results in still high germination after sediment resuspension events and not a decrease of the recolonisation potential if the salinity is established. Sediment resuspension can change the species composition and reactivate a buried diaspore bank.

The results of this study are relevant for the recolonisation of the submersed macrophytes. At higher light conditions in laboratory studies the charophytes and angiosperms demonstrated a high recolonisation potential in the coastal lakes.

\section{ACKNOWLEDGEMENTS}

The work was supported by the State Agency for Agriculture, Environment and Rural Areas (LLUR, formerly LANU). The authors acknowledge Ulrike Hamann and Mandy Bahnwart for support and helpful comments.

\section{REFERENCES}

Acosta, L.W., M.R. Sabbatini, L.F. Hernandez \& O.A. Fernandez. 1998. Regeneration of reproductive structures of Potamogeton pectinatus, Ruppia maritima, Zannichellia palustris and Chara contraria: effect of temperature. Phyton Int. J. Exp. Bot., 63: 167-178.

Acosta, L.W., M.R. Sabbatini, R. Fernandez \& M.A. Burgos. 1999. Propagule bank and plant emergence of marcophytes in artifical channels of a temperate irrigation area in Argentina. Hydrobiologia, 415: 1-5.

Beijerinck, W. 1947. Zadenatlas der nederlandsche flora. Veenman, Wageningen.

van den Berg, M.S., M. Scheffer, H. Coops \& J. Simons. 1998. The role of characean algae in the management of eutrophic shallow lakes. J. Phycol., 34: 750-756.

Bertsch, K. 1941. Früchte und Samen: Ein Bestimmungsbuch zur Pflanzenkunde der vorgeschichtlichen Zeit. Ferdinand Enke, Stuttgart.

Blindow, I. 1992. Decline of charophytes during eutrophication: comparison with angiosperms. Freshwat. Biol., 28: 9-14.

Blindow, I. 2000. Distribution of charophytes along the Swedish coast in relation to salinity and eutrophication. Internat. Rev. Hydrobiol., 85: 707-717.

Bonis, A. \& P. Grillas. 2002. Deposition, germination and spatio-temporal patterns of charophyte propagule banks: a review. Aquat. Bot., 72: 235-248.

Casanova, M.T. \& M.A. Brock. 1990. Charophyte germination and establishment from the seed bank of an Australian temporary lake. Aquat. Bot., 36: 247-254.

Casanova, M.T., M.D. de Winton \& J.S. Clayton. 2003. Do charophytes clear turbid waters? International Association of Theoretical and Applied Limnology, 28: 1440-1443.

Caspers, H. 1959. Vorschläge einer Brackwassernomenklatur (The Venice System). Internat. Rev. Hydrobiol, 44: 313-316. 
Clayton, J.S. \& C.C. Tanner. 1988. Selective control of submerged aquatic plants to enhance recreational uses of water bodies. Verh. Internat. Verein. Limnol., 23: 1518-1521.

Dugdale, T.M., M.D. de Winton \& J.S. Clayton. 2001. Burial limits to the emergence of aquatic plant propagules. $N$. $Z$. J. Mar. Freshwat. Res., 35: 147-153.

Ellenberg, H. 1992. Zeigerwerte von Pflanzen in Mitteleuropa. Erich Goltze, Göttingen: $258 \mathrm{pp}$.

En-Hua, L., L. Gui-Hua, L. Wei, Y. Long-Yi \& L. ShouChun. 2008. The seed-bank of a lakeshore wetland in Lake Honghu: implications for restoration. Plant Ecol., 195: 6976.

Frankland, B., M.R. Bartley \& D.H.N. Spence. 1987. Germination under water. In: R.M.M. Crawford (Ed.), Plant Life in Aquatic and Amphibious Habitats. Blackwell Scientific Publishing: Oxford: $452 \mathrm{pp}$.

James, W.F., J.W. Barko \& M.G. Butler. 2004. Shear stress and sediment resuspension in relation to submersed macrophyte biomass. Hydrobiologia, 515: 181-191.

Krause, W. 1997. Charales (Charophyceae) Bd. 18. In: Ettl, M., Gaertner, G., Heynig, H. \& Mollenhauer, D. (Eds), Süßwasserflora von Mitteleuropa. Gustav Fischer, Stuttgart: 202 pp.

Kufel, L. \& I. Kufel. 2002. Chara beds acting as nutrient sinks in shallow lakes - a review. Aquat. Bot., 72: 249-260.

Kuhnt, G., S. Börner \& H. Rotermund. 1990. Hydrologischumweltchemische Untersuchung des Windebyer Noores. Bericht im Auftrag des Magistrats der Stadt Eckernförde, Geographisches Institut der Universität Kiel: 67 pp.

Larson, O. \& C. Pohl. 2006. Modellierung des Salzgehaltes von Strandseen an der Ostsee unter ungestörten Bedingungen. Bericht für das Landesamt für Natur und Umwelt des Landes Schleswig-Holstein: 121 pp.

LAWA-Arbeitskreis 'Gewässerbewertung - stehende Gewässer. 1998. Vorläufige Richtlinie für eine Erstbewertung von natürlich entstandenen Seen nach trophischen Kriterien.Länderarbeitsgemeinschaft Wasser (Hrsg.): 74 pp.

Lüders, G.H. 1972. Das Windebyer Noor. Jahrbuch Eckernförde: 33-50.

Ostendorp, W. 1998. Hemmenhofener Methoden - Sedimentologische und paläolimnische Methoden in der Siedlungsarchäologie. Forsch. Ber. Vorgesch. Frühgesch. BadenWürtt., 68: 243-299.

Rothmaler, W., R. Schubert \& W. Vent. 1994. Exkursionsflora von Deutschland-Gefäßpflanzen: Kritischer Band. Gustav Fischer, Jena: $811 \mathrm{pp}$.

Sabbatini, M.R., J.A. Arguello, O.A. Fernandez \& R.A. Bottini. 1987. Dormancy and growth-inhibitor levels in oospores of Chara contraria A. Braun ex Kütz. (Charophyta). Aquat. Bot., 28: 189-194.

Sagert, S., U. Selig \& H.G. Wagner. 2008. Bewertung der Strandseen anhand von Makrophyten. Rostock. Meeresbiol. Beitr., 20: 71-89.

Received: June 2010

Accepted: September 2010
Schubert, H. \& I. Blindow. 2003. Charophytes of the Baltic Sea. Baltic Marine Biologists Publication 19. Koeltz Scientific, Königstein: 326 pp.

Sederias, J. \& B. Colman. 2007. The interaction of light and low temperature on breaking the dormancy of Chara vulgaris oospores. Aquat. Bot., 87: 229-234.

Selig, U., A. Eggert, D. Schories, M. Schubert, C. Blümel \& H. Schubert. 2007. Ecological classification of macroalgae and angiosperm communities of inner coastal waters in the Southern Baltic Sea. Ecol. Indicators, 7: 665-678.

Soulié-Märsche, I. 1989. Etude comparée de gyrogonites de Charophytes actuelles et fossiles et phylogénie des genres actuels. Imprimerie des Tilleuls, Millau, France: $237 \mathrm{pp}$.

Steinhardt, T. \& U. Selig. 2007. Spatial distribution patterns and relationship between recent vegetation and diaspore bank of a brackish coastal lagoon on the southern Baltic Sea. Estuar. Coast. Shelf Sci., 74: 205-214.

Steinhardt, T. \& U. Selig. 2009. Comparison of recent vegetation and diaspore banks along abiotic gradients in brackish coastal lagoons. Aquat. Bot., 91: 20-26.

Vedder, F. 2004. Morphologie und Taxonomie rezenter und subfossiler Characeen-Oosporen aus der Ostsee. Rostock. Meeresbiol. Beitr., 13: 43-54.

Wells, R.D.S., M.D. de Winton \& J.S. Clayton. 1997. Successive macrophyte invasions within the submerged flora of Lake Tarawera, Central North Island, New Zealand. N. Z. J. Mar. Freshwat. Res., 31: 449-459.

van de Weyer, K. \& C. Schmidt. 2007. Bestimmungsschlüssel für die aquatischen Makrophyten (Gefäßpflanzen, Armleuchteralgen und Moose) in Deutschland. Ministerium für Ländliche Entwicklung, Umwelt und Verbraucherschutz des Landes Brandenburg. www.mluv.brandenburg.de/cms/ detail.php/bb2.c.416666.de.

van Wijk, R.J. 1989. Ecological studies on Potamogeton pectinatus L. III. Reproductive strategies and germination ecology. Aquat. Bot., 33: 291-299.

Winter, U., I. Soulié-Märsche \& G.O. Kirst. 1996. Effects of salinity on turgor pressure and fertility in Tolypella (Characeae). Plant, Cell and Environment, 19: 869-879.

de Winton, M.D. \& J.S. Clayton. 1996. The impact of invasive submerged weed species on seed banks in lake sediments. Aquat. Bot., 53: 31-45.

de Winton, M.D., J.S. Clayton \& P.D. Champion. 2000. Seedling emergence from seed banks of 15 New Zealand lakes with contrasting vegetation histories. Aquat. Bot., 66: 181-194.

Wood, R.D. \& K. Imahori. 1965. Monograph of the Characeae. J. Cramer, Weinheim: 349-354.

Wu, J., S. Cheng, W. Liang, F. He \& Z. Wu. 2009. Effects of sediment anoxia and light on turion germination and early growth of Potamogeton crispus. Hydrobiologia, 628: 111119. 